Saudi Journal of Humanities and Social Sciences

Abbreviated Key Title: Saudi J Humanities Soc Sci

ISSN 2415-6256 (Print) | ISSN 2415-6248 (Online)

Scholars Middle East Publishers, Dubai, United Arab Emirates

Journal homepage: https://saudijournals.com

Original Research Article

\title{
Political Participation in Multi-Cultural Context: A Study of Ampara District in Sri Lanka
}

Athula Withanawasam $^{1 *}$

${ }^{1}$ Senior Lecturer and Head of the Department, Department of Political Science, University of Peradeniya, Peradeniya 20400, Sri Lanka

DOI: $10.36348 /$ sjhss.2021.v06i04.001

| Received: 26.02.2021 | Accepted: 29.03.2021 | Published: 02.04.2021

*Corresponding author: Athula Withanawasam

Abstract

The major objective of this study is to identify the nature of political participation of different groups in a multicultural communal context. The study was carried out based in the Ampara District in the eastern province of Sri Lanka. The Ampara district has been a multicultural space from the formation of the district in 1961 and has been influential in electoral politics in ethnic context. This study has incorporated both primary and secondary data collected from different sources. The collected data has been descriptively analyzed. The study has found that 'patron-client relationship' of the political culture working as a mobilizing initiator for electoral turnout among the three major ethnic groups in the district. However, establishment of the distinctive political party for their own, Muslims of the coastal area of the district marked a major departure point of the community's pattern of political participation. This development was a reaction to intense ethnic conflict between two major constituent ethnic groups of the country, i.e. Sinhalese and Tamils. The study has also found that there is a different pattern of political participation between the traditional inhabitant Sinhalese and the settlers in colonization schemes in the district. The traditional villagers show less interest in electoral politics while Sinhalese in the colonies have been very active. This is a shared feature of both Muslims and Sinhalese living in the colonies. On the other hand, the Tamils living in the area tends to amend to the political orders of the Tamils political elite based in Colombo and Jaffna. They tended to isolate themselves from other political parties. The study concludes that until Sri Lanka find a lasting political solution to the ethnic issue, segregation and fragmentation in multi-cultural context remains the pattern of electoral politics and building an overall Sri Lankan identity is next to impossible.

Keywords: Political Participation, multi-cultural context, Elections, Patron Client Relationship, political elite, Colonization schemes.

Copyright (C) 2021 The Author(s): This is an open-access article distributed under the terms of the Creative Commons Attribution 4.0 International License (CC BY-NC 4.0) which permits unrestricted use, distribution, and reproduction in any medium for non-commercial use provided the original author and source are credited.

\section{INTRODUCTION}

This study is on the political participation in a multi-cultural context. Sri Lanka was regarded as an ideal Third World Democracy [1]. However, that reputation belongs to past era. Sri Lanka has become a nation state where different ethnic groups quarrel with one another. This is because it has been unable to establish an over-reaching shared identity for each and every multi-cultural group of the political community. In this context, the ethnic conflict of Sri Lanka has become a testing ground of theories on ethnic conflict and resolution.

The literature on ethnic problem and political violence has made references to the lack of meaningful opportunities for minority groups to be represented in decision making process of the country. The scholars and agitators of ethnic groups have frequently pointed out that the electoral system since $1930 \mathrm{~s}$ has contributing to the system of majoritarian supremacy in public policy decision making process of the country [2]. However, there are few studies that focus on the nexus between ethnic problem and electoral politics in the multicultural context of Sri Lanka. Researchers have examined the pros and cons of political participation. However, there are a few studies on political participation in Sri Lanka. The above little literature has not paid any attention to political participation in multicultural context. The major thrust of the present study was to fill the above lacuna in the scholarship of Sri Lankan Politics.

The passing remarks made by earlier scholars in the field have discussed the role of the opposition and electoral politics [3, 4]. Weerawardana in his pioneering study on Electoral politics in Sri Lanka discussed the forces behind 1956 general election that changed a 
government through democratic means in the first time for Sri Lanka [5]. Warnanapala has discussed and analysed the electoral violence during 2001 general elections [6]. The economic and cultural forces behind Sri Lankan elections have been analysed by Wiggins [7]. Wilson has discussed the voter mobilization with specific focus on 1970 general election [8]. The cultural groups and strategic allegiance formation among the Sinhalese aimed at electoral victory has already been studied [9]. However, this scholarship has neither explored the strategical allegiance formation among ethnic communities nor the group mobilization with reference to elections in a truly multi-cultural context of Sri Lanka treated rigorously. In this study, an attempt was made to analyse the reasons for segregated and grouped voting in the multi-cultural district of Ampara in the eastern province of Sri Lanka. However, it must be noted that the present study did not attempt to explore the nature of political participation at elections and voter mobilization.

\section{METHODOLOGY OF THE STUDY}

This study was conducted using both primary and secondary data. Primary data was gathered using different techniques that belong to the qualitative tradition of reasoning and research. They included key informant discussions, focus groups interviews, in-depth interviews and field notes. Secondary data was extracted from publications of government departments as well as other organizations that have been active in electoral process in the District. For the purpose of the analysing the electoral participation and electoral behavior of different (multicultural) groups in Ampara district, only the election data from 1965 to 1989 are used in this study. The data descriptively analyzed for this study attempted to explore the pattern of electoral political participation among the different ethnic groups in the district. The reasons for qualitative analysis were the political participation and reasons behind the pattern of voter mobilization which could not be comprehended and analysed comprehensively by quantitative techniques such as sample testing or computer-based analysis. They tend to dictate the research by the research techniques themselves. However, in this paper, only the summaries of the findings are presented without detailed disclosure of primary data.

\section{Multi-Cultural Communities of Ampara District}

The Ampara district also shares many things common with the other districts of Sri Lanka in the sense that its population is multicultural communities. However, the particularity of the district lies in the fact that no ethnic community can override the other ethnic groups unlike the rest of the districts in the country. Table-1 presents the ethnic composition of the population of the District.

Table-1: Population of Amparai district by Ethnic Group (1963-2012)

\begin{tabular}{|l|l|l|l|l|l|l|l|l|l|}
\hline \multirow{2}{*}{ Census Year } & \multicolumn{2}{l}{ SL Muslims } & \multicolumn{2}{l|}{ Sinhalese } & \multicolumn{2}{l|}{ SL Tamils } & \multicolumn{2}{l|}{ Others } \\
\cline { 2 - 10 } & No & $\%$ & No & $\%$ & No & $\%$ & No & $\%$ & \\
\hline 1963 & 97,621 & 46.11 & 61,996 & 29.28 & 49,185 & 23.23 & 2,930 & 1.38 & 211,732 \\
\hline 1971 & 126,365 & 46.35 & 82,280 & 30.18 & 60,519 & 22.20 & 3,441 & 1.26 & 272,605 \\
\hline 1981 & 161,568 & 41.45 & 146,943 & 37.78 & 77,826 & 20.01 & 2.633 & 0.67 & 388,970 \\
\hline 2012 & 281,702 & 43.38 & 252,458 & 38.88 & 112,457 & 17.31 & 2,785 & 0.43 & 649,402 \\
\hline
\end{tabular}

Source: [See Ref: 10, 11]

The above table reveals that Muslims form the numerical majority of the population of the district. In the course of time, Sinhalese has increased their presence in the area due to political decisions taken by the central government. However, the above statistics secrets the ontological reality of multiculredness of the district. There are differences among the Muslims in terms of religious sects. The Sinhalese has also got significant differences in terms of traditional villagers and the people living in the colonies. The category of Tamils includes Sri Lankan Tamils as well as Tamils of Indian origin.

The Muslims have found their habitat mostly in coastal areas of the District. The areas where Muslims form the majority, such as Kalmunai, Akkaraippatthu and Sammanthurai witnesses high level of population density. Unlike the Muslims in the rest of the country, these Muslims shared many things with the peasantry of either Tamil or Sinhalese because they depend heavily on agriculture and fishing in meeting their means of living. They also share the vestiges of Tamil dominant culture of the South India such as land tenure system called 'podiyar'. Podiyar is the land owner and chief benefactor of the Muslims of rank and file of the society $[12,13]$. This high status ascribed upon them, has made them the political leaders at the grassroots level. The population density has increased group sentiments among them. These socio-economic and cultural practices have continued to influence electoral turn out of the district.

Sinhalese in the district are composed of two types of peoples, i.e. traditional villagers and those who have settled in government-sponsored colonization schemes. The traditional villagers explain that they are descendent of Uva-Wellassa Rebel of 1848. They have been in the habit of having a secluded life style and they have got enough lands to engage in traditional agriculture of slash and burn which is known as Chena cultivation [14]. The counterpart of podiyar of Muslims is the 'Gamarala' among the Sinhalese. Gamarala was 
the landowner and political leader. He acted as the chief benefactor of the villagers and one who communicated the minor grievances of the community to the political leadership [15]. However, the people living in colonies differ significantly from the traditional Sinhalese villagers for they had come to the district as new settlers from different socio-economic backgrounds representing different areas of the country. In a sense, they have received political patronage because they have been chosen on political allegiance to the party in power. Hence, the social bond among them remains very weak and has become dependent on political patronage over and over again.

Tamils of the district are basically concentrated in areas of Thirukkovil, Alayadivembu, Karaitivu and Kalmunai North. They have been living in those areas for generations. Their main means of living is either agriculture or fishing. What is observable of them is the lack of their own political leadership. The social norm of caste value is more prevalent among them. The official records in the parliament and other means of communication revealed that their economic and social wellbeing remained less visible in the policy making deliberation. One of the reasons for this situation has to do with political leadership was provided for them by the Northern elite. In the cultural context, they are a minority among the minority in Sri Lankan politics and can be regarded as the innocent of the innocent. The villagers have expressed that they would not find any solution to their problems because neither Sinhalese political leadership nor Muslim political leadership keen on addressing their issues in the culturally segregated political setup. According to their explanation, the mainstream Tamil political leadership opted to sit in the opposition camp as a habit. The villagers explained that children of Muslim community who lived outside the district came there in search of quality education in Tamil Medium while the Tamils of the district had to go other places in search of quality education. That was because Muslim Schools in the area did not tolerate other religious practices in Schools which have been defined as Muslims schools.

\section{Politics of Demarking of Ampara District}

Initially, Ampara was a part of the Batticaloa district - one of the two districts in the eastern province at that time. It was carved out from the southern part of that Batticaloa district [16]. The debates in the national parliament reveal that there were ethnic politics behind the carving out of this particular administrative district [17]. The minorities perceive the move of the government as an attempt to lessen the numerical strength of the Tamils of the Eastern Province and their presence in the national parliament [18]. Their argument is that it was a systematic administrative and political step taken by the Sinhalese government to curb and contain the traditional homeland of the TamilSpeaking Community. Yet the Muslims perception was somewhat different. Though they speak Tamil language and share many things in common with the Tamil community, they have opposed the assimilation strategy adopted by Tamil political elite. They perceived of themselves as a distinct identity group having their own culture. They did not oppose the idea of a separate administrative unit but over the location of the administrative headquarters of the district. They wanted it to be located in the Muslim majority area of Akkaraippattu or Kalmunai. The rationale of having such an idea was a cultural one. They pointed out, that if the administrative headquarters of the district is located in a Sinhalese-Majority Area, the womenfolk of their community have to venture out of their cultural habitat and it would damage their culture in different ways [16]. On the other hand, the Sinhalese dominated government have engaged in colonization schemes with different purposes. However, the annexing parts of Moneragala and Polonnaruwa districts in different phases were politically motivated and aimed at diminishing Tamil dominancy of the Eastern Province. For whatever reason, the present day Ampara district now has become a multi-cultural and diverse district in Sri Lanka.

\section{Voting Behavior in the Ampara District}

The observation of voter turn-out in the Ampara (named as "Digamadulla" for electoral purpose) district both under First-Past-the Post (PPP) system and Proportional Representative System revealed a significant difference of voter behavior in the District. Table-2 indicates the pattern of voting by registered voters under the First-Past-the-Post electoral system in different electorates in the district.

Table-2: Voting by Registered Voters under PPP Electoral System in Amparai district (1965-1977)

\begin{tabular}{|l|l|l|l|l|l|l|}
\hline Electoral Division & Vote Cast in 1965 & \% & Vote Cast in 1970 & \% & Vote Cast in 1977 & \% \\
\hline Kalmunai & 19,247 & $86 \%$ & 21,673 & $88 \%$ & 26,005 & 90 \\
\hline Nintavur & 23,399 & $88 \%$ & 27,527 & $93 \%$ & ------ & \\
\hline Pottuvil & 19,401 & $82 \%$ & 25,309 & $89 \%$ & 44,935 & \\
\hline Ampara & 24,748 & $75 \%$ & 33,398 & $79 \%$ & 41,696 & $90 \%$ \\
\hline Sammanthurai & ---- & ----- & ---- & ---- & 24,944 & $85 \%$ \\
\hline
\end{tabular}

Source: [See Ref: 19, 20, 21]

The above data reveals that this district could be distinguished from the rest of the electorates in other administrative districts of Sri Lanka. The electorates situated within the district have recorded high electoral 
turn-out, sometimes, paralleling the electoral turn outs to countries where voting has been made compulsory. The high electoral turn outs have been a result of high voter turnouts in the densely populated MuslimMajority electorates. The Sinhala majority electorate, i.e. Ampara has recorded the lowest voter turnout in every election. The difference needs special attention in analyzing the voter behavior in the district to understand how multi-cultural context affects on voting.
The electoral turnouts in the respective polling divisions in the district have shown the same trend under the Proportional Representative (PR) electoral system. Table- 3 presents the number of the registered voters and percentage of votes cast in the General Election of 1989 and Northern and Eastern Provincial Council Election of 1988, for example.

Table-3: Voting by Registered Voters under PR Electoral System in Amparai district (1988-1989)

\begin{tabular}{|c|c|c|c|c|c|}
\hline \multicolumn{3}{|c|}{ General Election 1989} & \multicolumn{3}{|c|}{ Provincial Council Election 1988} \\
\hline $\begin{array}{l}\text { Name of the } \\
\text { Electorate }\end{array}$ & $\begin{array}{l}\text { No. of Registered } \\
\text { Vote }\end{array}$ & $\begin{array}{l}\text { Percentage of vote } \\
\text { Cast }\end{array}$ & $\begin{array}{l}\text { Name of the } \\
\text { Electorate }\end{array}$ & $\begin{array}{l}\text { No. of Registered } \\
\text { Vote }\end{array}$ & $\begin{array}{l}\text { Percentage of } \\
\text { votes cast }\end{array}$ \\
\hline Ampara & 92,901 & 76.68 & Ampara & 94,068 & 5.79 \\
\hline Sammanthurai & 44,453 & 91.83 & Sammanthurai & 44,975 & 84.75 \\
\hline Kalmunai & 43,579 & 84.27 & Kalmunai & 44,075 & 89.93 \\
\hline Pottuvil & 82,231 & 88.97 & Pottuvil & 82,833 & 75.75 \\
\hline Total & 265,768 & 84.45 & Total & 265,951 & 54.94 \\
\hline
\end{tabular}

Source: [ See Ref: 22, 23].

The data in the above table needs to be understood in the then prevailing conditions of the country. The provincial council election was held in a context of political violence unleashed by both JanathaVimukthi Peramuna (JVP) and Liberation Tigers of Tamil Eelam (LTTE). The influence of the JVP was more visible in the Ampara polling divisions where Sinhalese form the majority of voters. The JVP called for a boycott of the provincial council. As result the electoral turnout in the Amparai polling division became very low. The Tamil population also prevented themselves from voting due to LTTE pressure to prevent going to the polling booth where their rival group EPRLF (Eelam Peoples' Revolutionary Liberation Front) contested the provincial council election adopting a pro-government and pro-India stance. However, the Muslims had gone to the polling booths and the electoral turnouts remained high when compared with the rest of the electoral districts of the country. The defeat of the JVP by military means resulted in increasing the voter turnout in the Ampara polling division to the normal situation at the general election of 1989. It was observable that the interest shown by the Muslims of the district was behind the high voter turnout under whatever electoral system.

It is also worth noting that the impact of civil war - particularly the negative impact on culture and religion - has influenced the shift in political and voting culture of Muslim community. During the civil war, Muslims in the eastern province naturally realized that they have been trapped in the arms struggle involving two groups: LTTE rebel group and Sri Lankan army. Because Muslims who are culturally and religiously separated from other ethnic groups, they were targeted by the LTTE and Sri Lankan Army during the war time. In this context, the primary challenge that the leaders of the Muslim Congress faced was how to protect their people from the arms struggle because they considered and voiced that they are the guardian of Muslim community [24].

Until the formation of Sri Lanka Muslim Congress (SLMC), Muslims did not have their own political party based on their ethnicity or religion. From the beginning, as an ethno-religious political party, SLMC leaders raised their voice for the voiceless Muslims. Therefore, within the electoral political sphere, they could maintain solid and overwhelming majority among Muslim community. Such achievement ensured that the Muslim Congress could share the governmental power through coalition partner with major parties from time to time. This electoral strategy has been important to the party to maintain its position as a champion of voters' identity-based rights. Moreover, it was able to deliver patronage goods services to regional base particularly the coastal areas of Ampara district to pursue their regional developments goals. Therefore, as guardian and service provider, SLMC was able to survive even in electoral sphere without facing any difficulty or challenge. Successive elections have shown the increased support of Muslim community to the newly formed SLMC.

\section{Electoral Culture and the Voter}

The electoral turnouts in densely populated coastal belt of the Ampara district have always been very high. The high electoral turnouts and mobilizations in this area were related to political demographic factors. The land tenure system based on local elite known as Podiyar has also closely worked side by side with the political patronage system of the broader social system of Sri Lanka. Podiyar being the land owner he has got the capacity of addressing a large number of people of Muslim community who depended on his good will to earn the mere necessities of life, i.e. the 
survival needs. Tenant labourers have been dependent on him for his ability to control means of living available to the peasant. Political leadership has resorted to Podiyar to mobilise voters for electoral victory. During the First-Past-the-Post electoral system, the high-profile Muslim political leadership had constantly changed their party allegiance and won elections because of this social and political phenomenon [1].

The other factor behind the high electoral turnout is related to population density. As people have been living shoulder to shoulder, their solidarity is very high. That social solidarity made them to vote in mass. There was another psychosocial and cultural factor that promoted high electoral turnouts. The establishment of the Muslims Congress indicated a shift in the political alliance of the Muslim community. The party's stronghold is based on the Ampara district. The establishment of the party has increased the bargaining power of the Muslim Community $\left[24,{ }^{1}\right]$. The Muslim Community believe that the politics is the only way for them to acquire bargaining power in the social rewards allocation process of the central government. This is a significant departure from that Tamil Community.

The Tamils of the district show allegiance to the main political elite of the Jaffna peninsula. The Tamil political elite are in the habit of non-cooperating with the political leadership of the mainstream political process that has been dominated by the Sinhalese. There were meagre opportunities for a Tamil to get elected in the electorate under the First-Past-the-Post System. Tamils were able to secure a representation from the multi-member electorate of the Pottuvil under the above system. Under the Proportional Representative system too, they have been able to secure only one seat in the national parliament since 1989 as indicated in the Table-4.

Table-4: Elected Representation in Parliament in term of Ethnic Groups in Ampara District

\begin{tabular}{|l|l|l|l|l|}
\hline \multirow{2}{*}{$\begin{array}{l}\text { General } \\
\text { Election }\end{array}$} & \multicolumn{4}{|l}{$\begin{array}{l}\text { Elected members to Parliament in } \\
\text { terms of ethnic groups }\end{array}$} \\
\cline { 2 - 5 } & Sinhalese & Muslims & Tamils & Total \\
\hline 1965 & 01 & 03 & -- & 04 \\
\hline 1970 & 01 & 03 & -- & 04 \\
\hline 1977 & 01 & 03 & 01 & 05 \\
\hline 1989 & 04 & 01 & 01 & 06 \\
\hline
\end{tabular}

Source: Calculated by the researcher from the statistical data of Department of Elections.

\footnotetext{
1 Though the District became the multi-member electorate under Proportional Representative System, the traditional electorate was kept by the Election Commission for administrative purposes such as counting votes etc.
}

It was also observed that the Tamils perceived of them as a minority within the district for they also show a high-level ethnic solidarity. The scattered Tamil groups in the district vote together for Tamil political parties with the sole objective of increasing their visibility in the decision-making bodies. Still their mindset is formed not to take part in the government but to be in the opposition for they believed being in the opposing camp would help them in gaining the self-rule for the community. It was observed that this culture has resulted in less development in the Tamil-predominant areas of the district.

As discussed earlier, the Sinhalese of the Ampara district is not a homogenous group of people. They are composed of traditional villagers and settlers in the government sponsored colonization schemes. Ampara electorate has been the Sinhalese majority electorate. It also has recorded a less electoral turnout when compared with rest of the electorates of the district. How and why this less turnout has to do with the heterogeneity of the electorate itself is an interesting question. It is observed that the voters in the newly established colonizing schemes are higher than the voters in the traditional villages of the district. According to the field survey, there are many and varied reasons behind the high electoral turnout recorded in the new colonization schemes. They can be summed up as follows:

1. The beneficiaries of colonization schemes are from the districts which have been more politically educated and experienced with resource allocation process based on patron-client political culture of Sri Lanka.

2. They do not have relatives in the area and they have been dependent on the government for every kind of help and necessities. They have been cultivating in the lands which were given by the government, used water provided by the government, and depended on government services in every sphere of life.

3. The politicization of bureaucracy since 1950s has penetrated into their lives through bureaucracy itself.

4. Rapid population growth in colonies and lack of land and the resulting social problems have made them more and more dependent for everything on the government and politics.

The above situation of politics made the Sinhalese of the district more and more interested in accruing benefits out of electoral politics. They were not demand makers at the policy initiation stage but at the policy implementation stage [25]. This implies that they do not speak of the general interests of the community but the particularized demand makers demand for themselves i.e. demanding political intervention to secure a job or piece of land for the family members. 
The traditional villagers in the district are less interested in electoral politics. The main reasons for that disinterest are the isolated situations of the village and the life style of the people. They live far away from the access to main city and are engaged in slash-burnt agriculture. They also have been independent since they had depended on their own lands which were abundant during 1960s and 1970s. They had also shown apolitical attitudes as they were not reliant on government for each and everything of life except in obtaining annual license for government lands for Chena cultivation. The villages were characterized by a social hierarchy on ascribed values. In this context, traditional leadership known as 'Gamarala' became the link between those ordinary villagers and the mainstream political process of the country. Politicians often have sought their help in the electoral political game. Many elders of traditional villages have recollected their fast memories how they were mobilized by them to vote and benefits accrued by their interventions such as building roads and other public utilities in the traditional villages. However, due to war and opening up of jobs in the military services decreased the status and power of the 'Gamarala.' The war resulted in modernizing the traditional villages as a requirement of the war itself and war provided job opportunities for the youth of those villages.

\section{CONCLUSION}

The study helped to find out the multi-cultural context of the Ampara District is closely related to the pattern of political behavior of different ethnic groups with regards to elections. The population density in Muslim majority areas of the district and resulting ethnic solidarity made Muslims voters more and more interested in going to the polling booth and high electoral turnouts recorded in the district both under the First-Past-the-Post system and Proportional Representative system. Ethnic identity and sense of being a minority have made Tamils who are scattered in the district to vote for the Tamil candidates and Tamil political parties of the North - as the rule of their voting behavior.

On the other hand, the Sinhalese who were settled in the colonization schemes in the district have been made more and more interested in the electoral politics for they are dependent for each and every aspect of their life and the practical utility of securing the benefits out of electoral bargain through vote. The self-reliance of the traditional villagers made them less interested in the electoral political process.

The voter turnout in the Ampara district shared the common characteristics of the broader political culture of Sri Lanka based on patron-client politics. However, its form and character have differed significantly from the rest of the country. The linking point between the politicians and the voters among both traditional village of the Sinhalese and the Muslims is the leadership based on ascribed values. The 'Podiyar' among the Muslims and the 'Gamarala' among the Traditional Sinhalese had been playing a key role in mobilizing the voters for elections for the candidates and parties that won the blessing of those traditional leadership. Traditional land-owning elite having link with the dominant political elite in respective ethnic cum cultural groups mobilize voters during elections.

It is worth noting that the Muslims of the Ampara district had voted for the candidates and parties that had got the support of local political elite. However, they had broken their habit of fielding candidates under the banners of different parties after forming Sri Lanka Muslim Congress in 1986 based on the Muslim stronghold in the Ampara district. It marked a departure point of politics among the Muslim community. The establishment Sri Lanka Muslim Congress provided a bargaining power for the community in resource allocation process. This departure from the earlier pattern of electoral politics has to comprehend as a reaction to the ethnic politics or ethnicized electoral politics carried out by Tamil and Sinhalese political elites.

There is also a difference of political participation between traditional inhabitants in the villages and the inhabitants that were settled under colonization schemes of the government. The traditional Sinhalese villages have shown a disinterest in elections while the Sinhalese in the colonies inclined to polling booth very much. This has to do with the heavy dependence culture on government help by the inhabitants in these colonies. That mentality continues even to date for different reasons. The Muslims also showed a high degree of interest to vote for they think that they are a minority. The Tamils, not like the others, tended to isolate with government and showed a tendency of following the dictates of Tamil elite orders that were based in Colombo and Jaffna. They vote not to gain political patronage from the government of Sri Lanka, but to challenge the political supremacy of the state. The ethnic conflict is a political challenge ahead of Sri Lanka. The ethnicity-based suspicion made this multicultural community segregated and isolated. What is needed in the present context is the accommodative political space for difference of culture and pattern of diversity. Neither the constitutional policy nor subsidiary public policies on multicultural society have created a political space that could meet one another as equal to others. Until Sri Lanka find a lasting political solution to the ethnic problem, segregation and isolation would breed suspicion and hatred.

\section{REFERENCES}

1. Jupp, J. (1978). Sri Lanka: third world democracy. London: Frank Cass.

2. Tiruchelvam, N. (1981). Franchise, dissent and accountability. In KM de Silva (ed.). Universal franchise 1931-1981: The Sri Lankan 
experience. (pp. 167-169). Colombo: Department of Information, Government of Sri Lanka.

3. Amarasinghe, Y.R. (1998). Revolutionary idealism and parliamentary politics: A study of Trotskyism in Sri Lanka. Colombo: Social Scientists' Association.

4. Samaraweera, V. (1981). Sri Lanka Marxist in electoral politics 1947-1978. In KM de Silva (ed.). Universal franchise 1931-1981: The Sri Lankan experience. (pp. 127-146). Colombo: Department of Information, Government of Sri Lanka.

5. Weerawardana, I.D.S. (1960). Ceylon general election-1956. Colombo: M.D. Gunasena \& Co. Ltd.

6. Warnapala, W. (2004). Electoral politics in Sri Lanka: A study of the parliamentary general election of December 2001. Colombo: Godage Publishers.

7. Wriggins, H. (1960). Ceylon: Dilemmas of a new nation. Princeton, New Jersey: Princeton University Press.

8. Wilson, A.J. (1975). Electoral politics in an emergent state: The Ceylon General Election of May 1970. London: Cambridge University Press.

9. Jayanntha, D. (1992). Electoral allegiance in Sri Lanka. Cambridge: Cambridge University Press.

10. Department of Census and Statistics. (2007). Special enumeration-Eastern province 2007. Colombo: Department of Census and Statistics.

11. Department of Census and Statistics. (2014). Census of population and housing-2012 (New) Final report. Colombo: Department of Census and Statistics.

12. Rameez, A. (2018). Sociology of Sri Lankan Muslims: Dealing with different dimensions of Muslim society, Journal of Engineering and Applied Science, 13(7), 1782-1793.
13. McGilvray, D. (2008). Crucible of conflict: Tamil and Muslim society on the East coast of Sri Lanka. Colombo: Social Scientist Association.

14. Udawatta, P. (2013). Digamadulla. Meerigama: Akarshas Publishers.

15. Udawatta, P. (2006). Wewagampattuwe athto. Colombo: Godage Publishers.

16. Sarjoon, A., Yusoff, M.A., Hussin, N., \& Awang, A. (2015). The demand for an administrative district for the coastal belt of Amparai district in Sri Lanka: an assessment of its root causes, Mediterranean Journal of Social Sciences, 6(4S3), 434-443.

17. Hansard, 6 April, 1961.

18. Hansard, 7 June, 1961.

19. Department of Elections. (1966). Report on the Sixth parliamentary elections 1965. Colombo: Government Publication Bureau.

20. Department of Elections. (1971). Report on the Seventh General elections in 1970. Colombo: Government Publication Bureau.

21. Department of Elections. (1978). Report on the Eight Parliament election in 1977. Colombo: government Publication Bureau.

22. Department of Elections. (1989). Result of Parliamentary general election 1989. Colombo: Department of Elections.

23. Department of Elections. (1990). Report on the Provincial Council elections in 1988. Colombo: Elections Commissioner Office.

24. Yusoff, M.A., Sarjoon, A., Hussin, N., \& Ahmed, A. (2017). Analyzing the contributions of Sri Lanka Muslim Congress and its founderleader to Muslim politics and community in Sri Lanka, Social Sciences 6, 120.

25. Abeyrathne, G.D.R.U.U. (2005). Implementing public policies for poverty alleviation: A study of the Samurdhi programme of Sri Lanka (Unpublished M.Phil Thesis). Peradeniya: University of Peradeniya. 